\title{
Demersal resource assemblages in the trawl fishing grounds off the Balearic Islands (western Mediterranean)*
}

\author{
ENRIC MASSUTÍ and OLGA REÑONES \\ IEO, Centre Oceanogràfic de les Balears, P.O. Box 291, 07080 Palma de Mallorca, Spain. \\ E-mail: enric.massuti@ba.ieo.es
}

\begin{abstract}
SUMMARY: The demersal resources distributed in the trawl fishing grounds off the Balearic Islands (western Mediterranean) were studied from two bottom trawl surveys carried out in spring and autumn along the continental shelf and upper slope off the islands of Mallorca and Menorca. A total of 88 hauls, between 41 and $745 \mathrm{~m}$ depth, were analysed by means of multivariate analysis and ecological parameter calculation in order to characterise the structure of commercial species assemblages. A different bathymetric distribution of abundance was observed by comparing the main taxonomic groups. Six main species assemblages were identified, primarily associated with depth but also with different macro-epibenthic communities. Seasonal or geographic differences were detected for three of these assemblages, which could be related to differences in habitats and macro-epibenthic communities, as well as to seasonal changes in the abundance of some species related to their life cycle.
\end{abstract}

Key words: demersal resources, bathymetric distribution, species assemblages, macro-epibenthos, bottom trawl, Balearic Islands, western Mediterranean.

RESUMEN: ASOCIACIONES DE RECURSOS DEMERSALES EN LOS FONDOS DE ARRASTRE DE LAS ISLAS BALEARES (MEDITERRÁNEO OCCIDENTAL). - Se estudian los recursos demersales distribuidos en los fondos de arrastre de las Islas Baleares (Mediterráneo occidental), a partir de dos campañas de arrastre de fondo realizadas en primavera y otoño a lo largo de la plataforma continental y talud superior de las islas de Mallorca y Menorca. El análisis multi-variante de un total de 88 pescas entre 41 y $745 \mathrm{~m}$ de profundidad y el cálculo de parámetros ecológicos ha permitido caracterizar la estructura de las asociaciones de especies comerciales. Se ha observado una distribución batimétrica diferente en la abundancia de los principales grupos taxonómicos y se han identificado seis grandes asociaciones de especies, relacionadas principalmente con la profundidad, aunque también con diferentes comunidades macro-bentónicas. Se han detectado diferencias estacionales y geográficas en tres de estas asociaciones, las cuales podrían estar relacionadas con diferencias en hábitats y comunidades macro-bentónicas, así como con cambios estacionales en la abundancia de algunas especies, debidos a sus ciclos vitales.

Palabras clave: recursos demersales, distribución batimétrica, asociaciones de especies, macro-epibentos, arrastre de fondo, Islas Baleares, Mediterráneo occidental.

\section{INTRODUCTION}

Demersal fish, crustacean and cephalopod assemblages in the Mediterranean Sea have been widely studied along the western (Demestre et al.,

*Received January 13, 2004. Accepted September 20, 2004.
2000; Abelló et al., 2002; González and Sánchez, 2002; and references cited therein), central (Biagi et al., 2002; Colloca et al., 2003) and eastern (Labropoulou and Papaconstantinou, 2000; Kallianiotis et al., 2000) coasts. As concerns the Balearic Islands, the available information is related to fish and crustacean assemblages on bathyal slope bot- 
toms off the southern islands (Moranta et aI., 1998; Maynou and Cartes, 2000, respectively) and to fish and cephalopod assemblages from the trawl fishery, carried out on the continental shelf and upper slope off Mallorca (Massutí et al., 1996; Moranta et al., 2000; Quetglas et al., 2000).

Assessments of some of the main species exploited by trawl fishery of the Balearic Islands have been made from analytic methods based on population dynamics (Oliver, 1993; GarcíaRodríguez and Esteban, 1999), production models (Carbonell and Azevedo, 2003) and regression analysis (Alemany and Álvarez, 2003). These assessments consider the single species as the basic unit of the analysis, which has been considered as incomplete for multi-species fisheries such as the Mediterranean bottom trawl (Caddy, 1993; Lleonart and Maynou, 2003). According to these authors, this fishery should require a multi-species and ecosystem-based approach, which takes into account all living organisms and the environment, with special emphasis on habitats, communities and the effect of inter-specific relationships on the species abundance and distribution (Caddy and Sharp, 1986).

The aim of the present paper is to characterise, from a quantitative point of view, the demersal assemblages exploited in the trawl fishery off the Balearic Islands (western Mediterranean), their structure and species diversity, and the macroepibenthic communities in which they are distributed.

\section{MATERIAL AND METHODS}

\section{Study area}

The Balearic Islands (Fig. 1) are separated from the Iberian Peninsula by large geographical barriers (depths of between 800 and $2000 \mathrm{~m}$ and a minimum distance of 93 nautical miles or $170 \mathrm{~km}$ ). In addition, they can be considered as an isolated exploited demersal ecosystem, also according to the fishing fleet structure, in which 346 small-scale boats and 61 trawlers operate, providing annual landings estimated at about 4,000 tonnes (Massutí, 1991).

The continental shelf of Mallorca and Menorca is narrow and consists mainly of a rocky coast, with predominance of sea-grass meadows and sand and sandy-muddy bottoms. The only exceptions are the northern and southern areas off Mallorca, where the bays of Alcudia, Pollença and Palma and the channels between Mallorca and Menorca and between Mallorca and Cabrera (Fig. 1) increase the presence of muddy-sand bottoms and enlarge the continental shelf. The slope is also very steep, with an absence of submarine canyons, and its morphology is conditioned more by emergent geological structures than by the input of sediment from the shelf. The absence of river runoff reduces the presence of terrigenous muddy sediments. Consequently, in contrast with the bottoms of the Iberian Peninsula, the muddy bottoms in the Balearic Islands area are mainly of biogenic origin (e.g. Canals and Ballesteros, 1997).

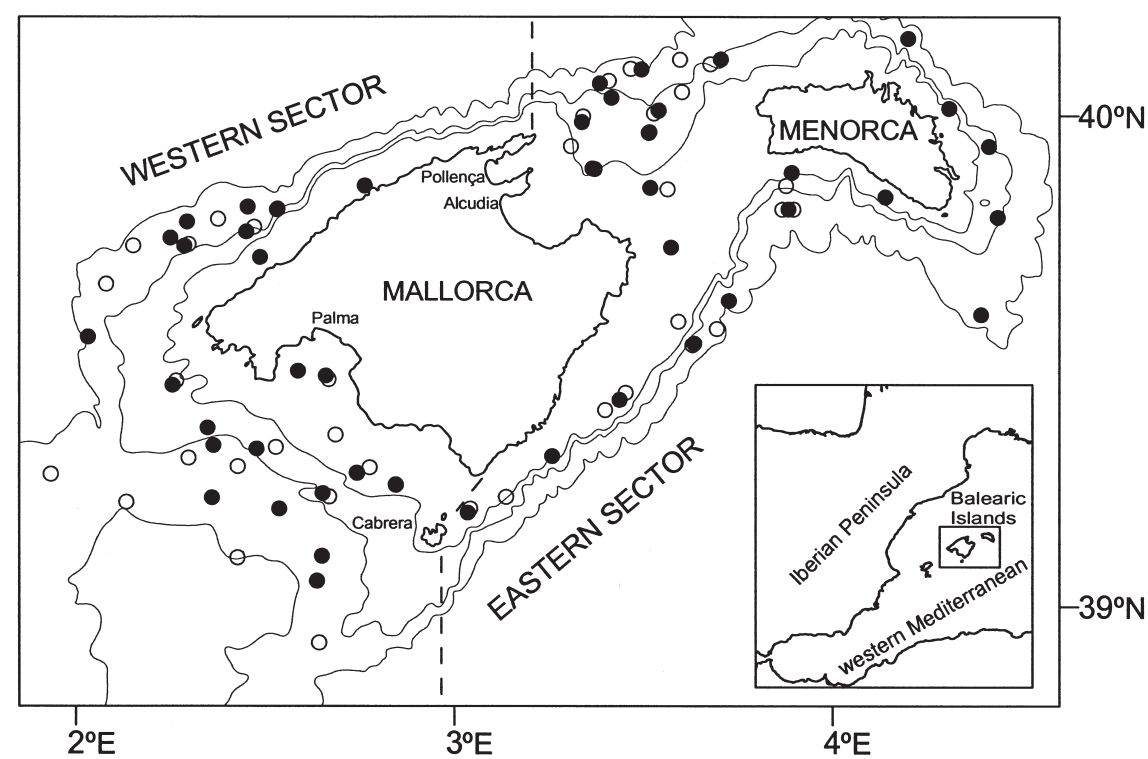

FIG. 1. - Maps of the studied area off Mallorca and Menorca Islands (Balearic Islands, western Mediterranean), showing the trawl samples made during the BALAR0401 (white circles) and BALAR0901 (black circles) cruises and the geographic sectors considered (western and eastern), which are separated by dashed lines. The 100, 200 and $800 \mathrm{~m}$ isobaths are shown. 
Table 1. - Major benthic communities identified during BALAR surveys according to Pérès (1985) and main macro-epibenthic species found.

\begin{tabular}{|c|c|c|}
\hline Benthic assemblage & Code & Macro-epibenthic taxa \\
\hline Soft red and green algae facies of sandy and gravel detritic bottoms & 1 & $\begin{array}{l}\text { Vidalia volubilis, Phyllophora nervosa, Peyssonnelia, } \\
\text { Codium bursa, Suberites domuncula, Spatangus purpureus, } \\
\text { Astropecten, Turritella, Pecten, Paguridae }\end{array}$ \\
\hline Calcareous red algae facies of sandy and gravel detritic bottoms & 2 & $\begin{array}{l}\text { Lithothamnion, Lithophyllum, Laminaria rodriguezii, } \\
\text { Suberites domuncula, Spatangus purpureus, Astropecten, } \\
\text { Turritella, Pecten, Paguridae }\end{array}$ \\
\hline Muddy-detritic assemblages & 3 & $\begin{array}{l}\text { Alcyonium palmatum, Aphrodite aculeata, Ophiothrix, } \\
\text { Phallusia mammillata, Diazona violacea, Microcosmus }\end{array}$ \\
\hline Shelf-edge detritic assemblages & 4 & $\begin{array}{l}\text { Alcyonium palmatum, Echinus, Astropecten, Ophiura, } \\
\text { Aporrhais }\end{array}$ \\
\hline Bottoms with large braquiopoda & 5 & Gryphus vitreus \\
\hline Bathyal muddy soft bottoms & 6 & $\begin{array}{l}\text { Pennatula, Veretillum, Cidaris cidaris, Brissopsis, } \\
\text { Mesothuria, Aporrhais, Xenophora, Sepiolidae, } \\
\text { Bathypolypus sponsalis, Polycheles typhlops, Munida, } \\
\text { Macropipus tuberculatus, Thenea muricata }\end{array}$ \\
\hline
\end{tabular}

The Balearic Islands are an area with high hydrographical variability, which is mainly conditioned by the water masses circulating through its channels (e.g. Pinot et al., 1995, 2002). As in the western Mediterranean, the thermal and saline conditions of the study area are highly stable below $200 \mathrm{~m}$ depth, with a salinity of 38.3-38.5 and a temperature of $13.0-13.5^{\circ} \mathrm{C}$. Above this depth, the surface temperature shows seasonal variations, ranging between $13^{\circ} \mathrm{C}$ during winter and $27^{\circ} \mathrm{C}$ in summer. In this period, a clear strong temperature gradient is established between depths of 50 and $100 \mathrm{~m}$ (Fernández-Puelles et al., 2004).

\section{Data source}

During 2001, two bottom trawl cruises were conducted in April (BALAR0401) and SeptemberOctober (BALAR0901), on board the R/V Francisco de Paula Navarro. They were undertaken in the trawl fishing grounds along the continental shelf and upper slope off Mallorca and Menorca (Balearic Islands, western Mediterranean; Fig. 1). The experimental hauls were performed according to a random stratified sampling strategy, taking into account depth and two geographic sectors (western and eastern; Fig. 1) established according to different trawl fleets working in the area (Carbonell et al., 2003).

The sampling gear used was a GOC73 trawl net, which has been used since 1994 for different surveys undertaken throughout the western Mediterranean and its efficiency for catching demersal species has already been tested (Bertrand et al.,
2002). The average towing speed was 2.8 knots. The average horizontal and vertical openings were estimated as 16.4 and $2.8 \mathrm{~m}$ respectively using SCANMAR system. The geographical position of each haul was recorded using GPS (Global Positioning System).

A total of 88 experimental hauls were conducted between depths of 41 and $745 \mathrm{~m}$ : 41 hauls (44-745 $\mathrm{m})$ during spring (BALAR0401) and 47 hauls (41$692 \mathrm{~m}$ ) during autumn (BALAR0901) (Fig. 1). The tows, conducted during daylight hours, had a duration of 20 to 60 minutes. The catch of each sample was identified to species level (except for some invertebrates, which could only be identified to generic level), counted, weighed and standardised to 30 minutes. The analysis of the main macro-epibenthic species caught on each haul was used to assign the sampling stations to one of the benthic communities characteristic of the circalittoral soft bottoms of the western Mediterranean (Pérès, 1985). It should be noted that the bottom trawl collected only epi-benthic species (Ellis et al., 2000). No infaunal data were used in the present study. The benthic communities found and their main macro-epibenthic species captured for each assemblage are shown in Table 1.

\section{Statistical analysis}

For the analysis of demersal resources, species that composed the bottom trawl fishery landings in the study area were considered (Carbonell, 1997). Species appearing fewer than three times on each 
TABLE 2. - Total abundance (A, in number of individuals), bathymetric range (D, in metres) and frequency of occurrence (\%, calculated as number of hauls in which the species appeared in relation to the total number of hauls analysed) of each commercial demersal species captured by the surveys BALAR0401 (Spring) and BALAR0901 (Autumn). Fishing time standardised to 30 minutes in each fishing operation.

\begin{tabular}{|c|c|c|c|c|c|c|c|}
\hline \multirow[b]{2}{*}{ Group/Family } & \multirow[b]{2}{*}{ Species } & \multicolumn{3}{|c|}{ BALAR0401 } & \multicolumn{3}{|c|}{ BALAR0901 } \\
\hline & & A & $\mathrm{D}$ & $\%$ & A & $\mathrm{D}$ & $\%$ \\
\hline \multicolumn{8}{|l|}{ FISHES } \\
\hline \multirow[t]{2}{*}{ Scyliorhinidae } & Galeus melastomus & 214 & $101-745$ & 37 & 1102 & $326-692$ & 36 \\
\hline & Scyliorhinus canicula & 925 & $44-400$ & 59 & 1767 & $46-416$ & 70 \\
\hline \multirow[t]{3}{*}{ Squalidae } & Centrophorus uyato & & & & 1 & 686 & 2 \\
\hline & Dalatias licha & 1 & 698 & 2 & 1 & 624 & 2 \\
\hline & Squalus blainvillei & 45 & $139-649$ & 5 & 14 & 103-399 & 8 \\
\hline \multirow{2}{*}{ Triakinidae } & Mustelus asterias & & & & 1 & 103 & 2 \\
\hline & Mustelus mustelus & & & & 1 & 68 & 2 \\
\hline \multirow[t]{9}{*}{ Rajidae } & $\begin{array}{l}\text { Raja asterias } \\
\text { Raja brachyura }\end{array}$ & 31 & $\begin{array}{c}44-389 \\
70\end{array}$ & $\begin{array}{c}27 \\
2\end{array}$ & 15 & $59-399$ & 13 \\
\hline & Raja clavata & 46 & $85-400$ & 24 & 47 & 103-399 & 30 \\
\hline & Raja microocellata & & & & 27 & $41-58$ & 8 \\
\hline & Raja montagui & & & & 3 & 77 & 2 \\
\hline & Raja miraletus & 80 & $53-167$ & 34 & 68 & $41-399$ & 28 \\
\hline & Raja naevus & 25 & $101-189$ & 17 & 26 & $52-337$ & 17 \\
\hline & Raja oxyrhinchus & 6 & $371-400$ & 7 & 10 & $235-444$ & 13 \\
\hline & Raja polistigma & & & & 8 & $63-127$ & 6 \\
\hline & Raja undulata & 2 & 53 & 2 & & & \\
\hline Chlorophthalmidae & Chlorophthalmus agassizi & 343 & $189-649$ & 19 & 782 & $180-444$ & 19 \\
\hline Congridae & Conger conger & 7 & $139-737$ & 19 & 6 & $63-692$ & 15 \\
\hline Ophichthidae & Echelus myrus & 1 & 96 & 2 & 1 & 92 & 2 \\
\hline Merluccidae & Merluccius merluccius & 59 & $44-737$ & 63 & 1203 & $52-686$ & 72 \\
\hline \multirow[t]{5}{*}{ Gadidae } & Micromesistius poutassou & 609 & $163-745$ & 27 & 61 & $326-686$ & 28 \\
\hline & Molva d. macrophthalma & 12 & $334-538$ & 15 & 16 & $337-494$ & 11 \\
\hline & Phycis blennoides & 295 & $139-745$ & 54 & 563 & $92-692$ & 55 \\
\hline & Phycis phycis & 1 & 74 & 2 & 9 & $72-146$ & 4 \\
\hline & Trisopterus m. capelanus & 235 & $91-189$ & 15 & 407 & $92-170$ & 19 \\
\hline Moridae & Mora moro & 13 & $388-745$ & 17 & 6 & $444-692$ & 15 \\
\hline Zeidae & Zeus faber & 40 & 53-189 & 32 & 41 & $41-155$ & 40 \\
\hline Serranidae & Epinephelus marginatus & 2 & 53 & 2 & & & \\
\hline & Serranus cabrilla & 483 & $44-163$ & 46 & 1395 & $41-146$ & 45 \\
\hline Cepolidae & Cepola rubescens & 85 & $69-153$ & 27 & 34 & $70-416$ & 19 \\
\hline Mullidae & Mullus barbatus & 1239 & $44-189$ & 29 & 1959 & $41-117$ & 15 \\
\hline & Mullus surmuletus & 959 & $44-538$ & 66 & 1474 & $41-337$ & 57 \\
\hline Sparidae & Diplodus annularis & 218 & 44 & 2 & 531 & $41-46$ & 4 \\
\hline & Diplodus puntazzo & 2 & 44 & 2 & & & \\
\hline & Diplodus vulgaris & 90 & $44-74$ & 5 & 123 & $41-63$ & 4 \\
\hline & Dentex dentex & 2 & 74 & 2 & & & \\
\hline & Pagellus acarne & 19 & $44-101$ & 7 & 485 & $41-103$ & 17 \\
\hline & Pagellus bogaraveo & 1 & 96 & 2 & 8 & $91-146$ & 4 \\
\hline & Pagellus erythrinus & 70 & $44-101$ & 15 & 300 & $41-103$ & 28 \\
\hline & Spondyliosoma cantharus & & & & 10 & 41 & 2 \\
\hline & Pagrus pagrus & 14 & 44 & 2 & 46 & 41 & 2 \\
\hline Centracanthidae & Spicara smaris & 2923 & 53-139 & 34 & 15538 & $41-144$ & 32 \\
\hline Labridae & Coris julis & 6 & 70 & 2 & 195 & $52-77$ & 8 \\
\hline Trachinidae & Trachinus draco & 365 & $44-167$ & 49 & 387 & $41-144$ & 40 \\
\hline & Trachinus radiatus & 216 & 44 & 2 & 19 & $41-59$ & 8 \\
\hline Uranoscopidae & Uranoscopus scaber & 32 & $44-153$ & 24 & 36 & $41-144$ & 23 \\
\hline Blenniidae & Blennius ocellaris & 57 & $44-139$ & 32 & 107 & $41-176$ & 42 \\
\hline Ophidiidae & Ophidion barbatum & 1 & 919 & 2 & 1 & 41 & 2 \\
\hline Centrolophidae & Centrolophus niger & 8 & $353-538$ & 10 & & & \\
\hline Scorpaenidae & Helicolenus dactylopterus & 187 & $153-538$ & 27 & 465 & $117-686$ & 45 \\
\hline & Scorpaena elongata & 1 & 189 & 2 & 3 & 180 & 2 \\
\hline & Scorpaena notata & 535 & $44-139$ & 27 & 581 & $41-160$ & 38 \\
\hline & Scorpaena porcus & 56 & $53-160$ & 15 & 22 & $41-74$ & 11 \\
\hline & Scorpaena scrofa & 56 & $44-139$ & 32 & 117 & $41-337$ & 45 \\
\hline Triglidae & Aspitrigla obscura & & & & 3 & $155-176$ & 6 \\
\hline & Chelidonichthys cuculus & 380 & 76-189 & 29 & 2209 & $70-235$ & 36 \\
\hline & Lepidotrigla cavillone & 1067 & $44-167$ & 49 & 1785 & $41-146$ & 30 \\
\hline & Trigla lucerna & 1 & 74 & 2 & 1 & 70 & 2 \\
\hline & Trigla lyra & 19 & 139-389 & 17 & 47 & $103-416$ & 30 \\
\hline & Chelidonichthys lastoviza & 374 & $44-101$ & 24 & 1103 & $41-91$ & 28 \\
\hline Peristeiidae & Peristedion cataphractum & 10 & $69-706$ & 19 & 41 & $52-686$ & 34 \\
\hline Dactylopteidae & Dactylopterus volitans & 4 & $44-53$ & 5 & 4 & 63 & 2 \\
\hline Citharidae & Citharus linguatula & 165 & $74-153$ & 22 & 183 & $92-103$ & \\
\hline Scophthalmidae & Lepidorhombus boscii & 80 & $97-436$ & 41 & 223 & $137-626$ & 45 \\
\hline & Lepidorhombus whiffiagonis & 3 & $189-371$ & 7 & 19 & $160-444$ & 17 \\
\hline Soleidae & Bathysolea profundicola & 1 & 436 & 2 & & & \\
\hline & Microchirus ocellatus & 2 & 58 & 2 & 1 & 52 & 2 \\
\hline
\end{tabular}


TABLE 2 (Cont.). - Total abundance (A, in number of individuals), bathymetric range (D, in metres) and frequency of occurrence (\%, calculated as number of hauls in which the species appeared in relation to the total number of hauls analysed) of each commercial demersal species captured by the surveys BALAR0401 (Spring) and BALAR0901 (Autumn). Fishing time standardised to 30 minutes in each fishing operation.

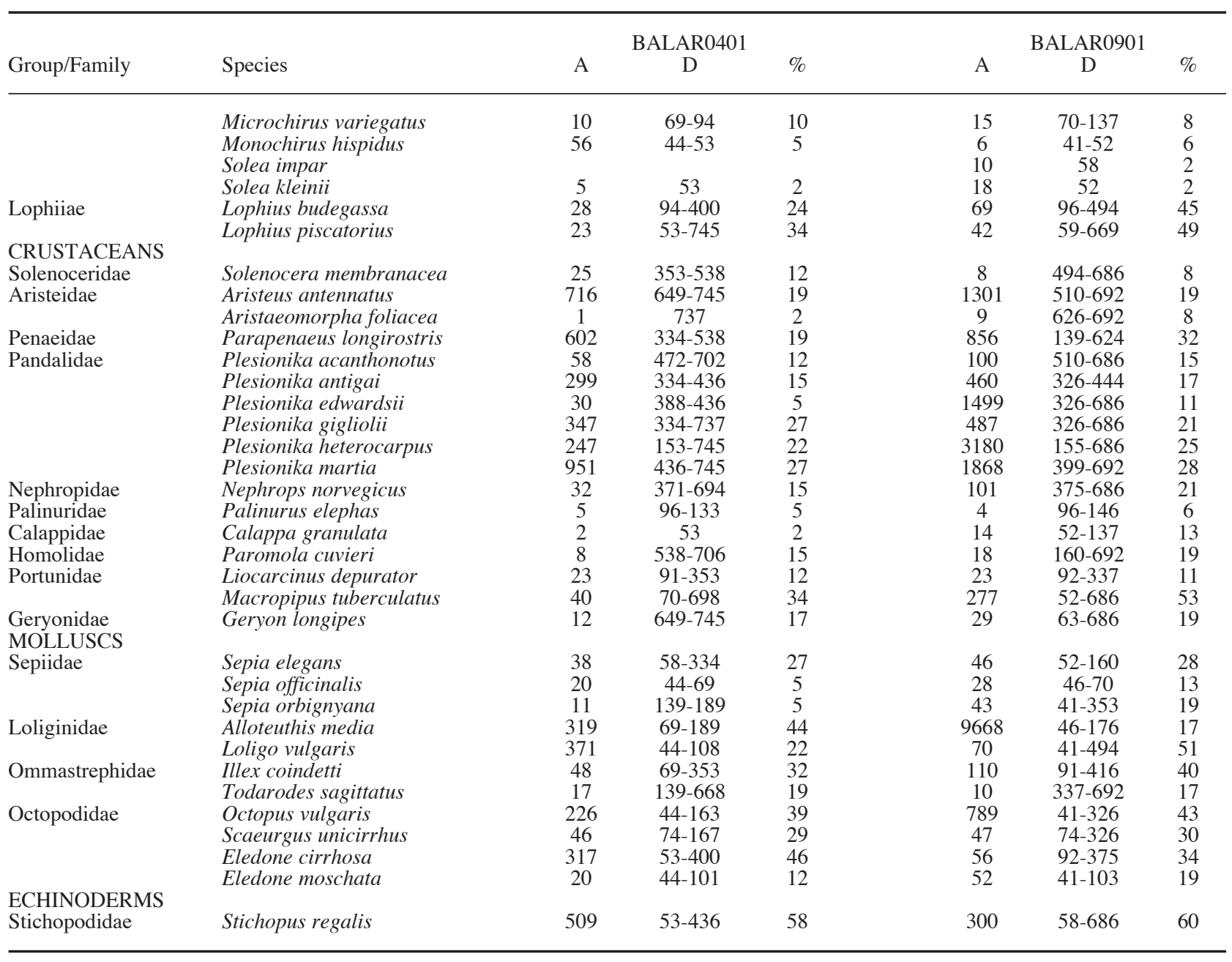

cruise, as well as species considered as pelagic or mesopelagic in previous studies in the area (Massutí et al., 1996; Moranta et al., 1998), were omitted from this analysis.

The bathymetric distribution of each species caught was analysed quantitatively by estimating the centre of gravity (COG; Daget, 1976) and habitat width (HW; Pielou, 1969). Both techniques have previously been applied to describe the bathymetric distribution of demersal fish species (e.g. Moranta et al., 1998). Before the analysis, the bathymetric range sampled was divided into eight strata of 100 m. COG and HW were calculated as follows: $\mathrm{COG}=$ $\left(\mathrm{x}_{1}+2 \mathrm{x}_{2}+3 \mathrm{x}_{3}+\ldots+\mathrm{nx}_{\mathrm{n}}\right) / \sum \mathrm{x}_{\mathrm{i}}$ and $\mathrm{HW}=\mathrm{e}^{\mathrm{H}}$, where $\mathrm{x}_{\mathrm{i}}$ represents the calculated mean abundance values of the species $x$ present in the stratum $i$, e is the natural $\log$ and $\mathrm{H}^{\prime}$ the Shannon-Wiener function $\left(\mathrm{H}^{\prime}=\right.$ $-\sum \mathrm{p}_{\mathrm{i}}{ }^{*} \log \mathrm{p}_{\mathrm{i}}$, where $\mathrm{p}_{\mathrm{i}}$ is the proportion of individuals of the species in the depth stratum).
In order to identify species assemblages, cluster analysis and non-metric multidimensional scaling (MDS) were applied after the double square root transformation had been performed. The percentage haul similarity was calculated by means of the Bray-Curtis index (Clifford and Stephenson, 1975) and the Unweighted Pair-Group Mean Analysis (UPGMA) was applied to link similar samples into clusters. All the analyses were carried out using the PRIMER package (Clarke and Warwick, 1994). Similarity percentage analysis (SIMPER) and analysis of similitude (ANOSIM) routines were also applied to identify the species that contributed most to each group and to detect seasonal and spatial differences within each of these assemblages respectively. Two levels of the two factors considered were (i) season (spring and autumn); and (ii) geographic sectors (western and eastern; Fig. 1). For each assemblage, mean abundance and total and mean species richness were calculated. 
To estimate the importance of the commercial species within the community and to provide an overview of their accompanying macro-epibenthos, the percentage of non-commercial and commercial species and the mean standardised capture, in terms of biomass, were calculated for each assemblage. The main taxonomic groups, algae, echinoderms, molluscs, crustaceans and fishes, were considered, while the less abundant taxa (sponges, cnidarians, annelids, brachiopods and ascidians) were grouped.

\section{RESULTS}

A total of 130,777 individuals belonging to 103 commercial demersal species (74 fishes, 17 decapod crustaceans, 11 cephalopod molluscs and 1 holoturoid echinoderm) were captured (Table 2).

\section{Bathymetric distribution of species}

On both cruises, abundance by depth showed a rather similar trend for each of the main taxonomic groups analysed (Fig. 2). However, large differences were observed by comparing bathymetric trends between groups. Fish abundance generally decreased throughout the whole bathymetric range surveyed. An increasing trend with depth was observed in decapod crustacean abundance, while an opposite trend was detected for cephalopod mollusc abundance. For the only echinoderm analysed (Stichopus regalis), the maximum abundance by
BALAR0401
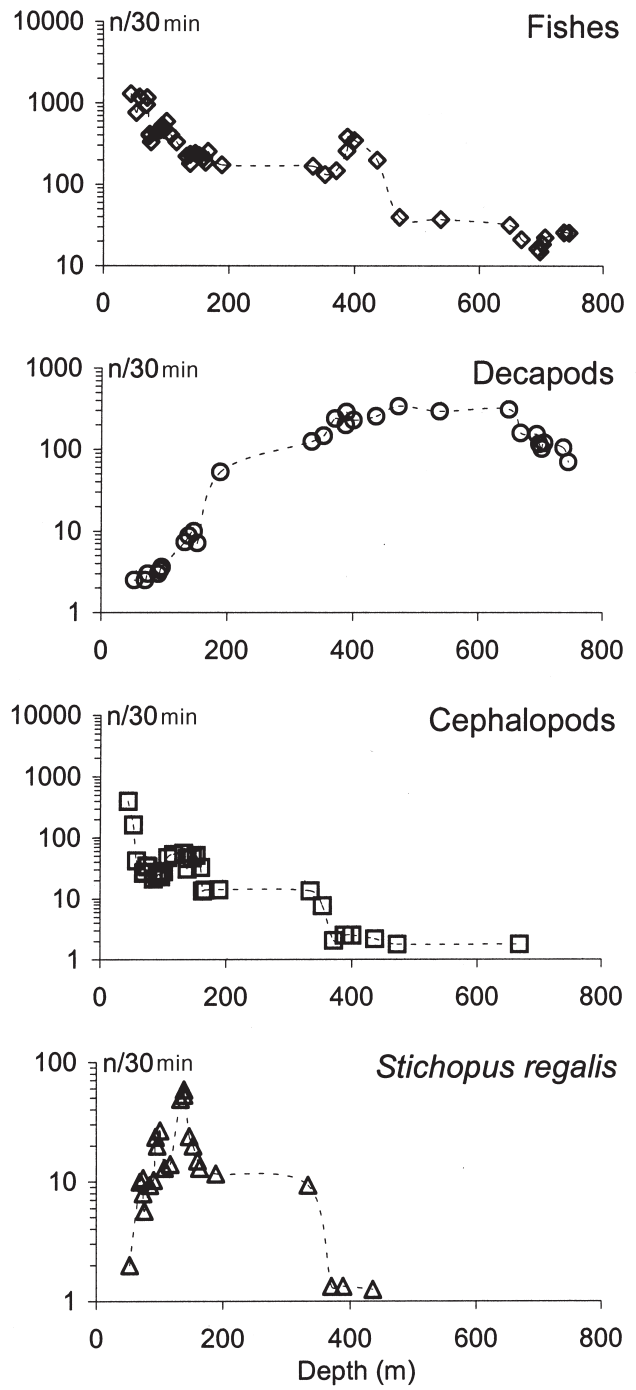

\section{BALAR0901}
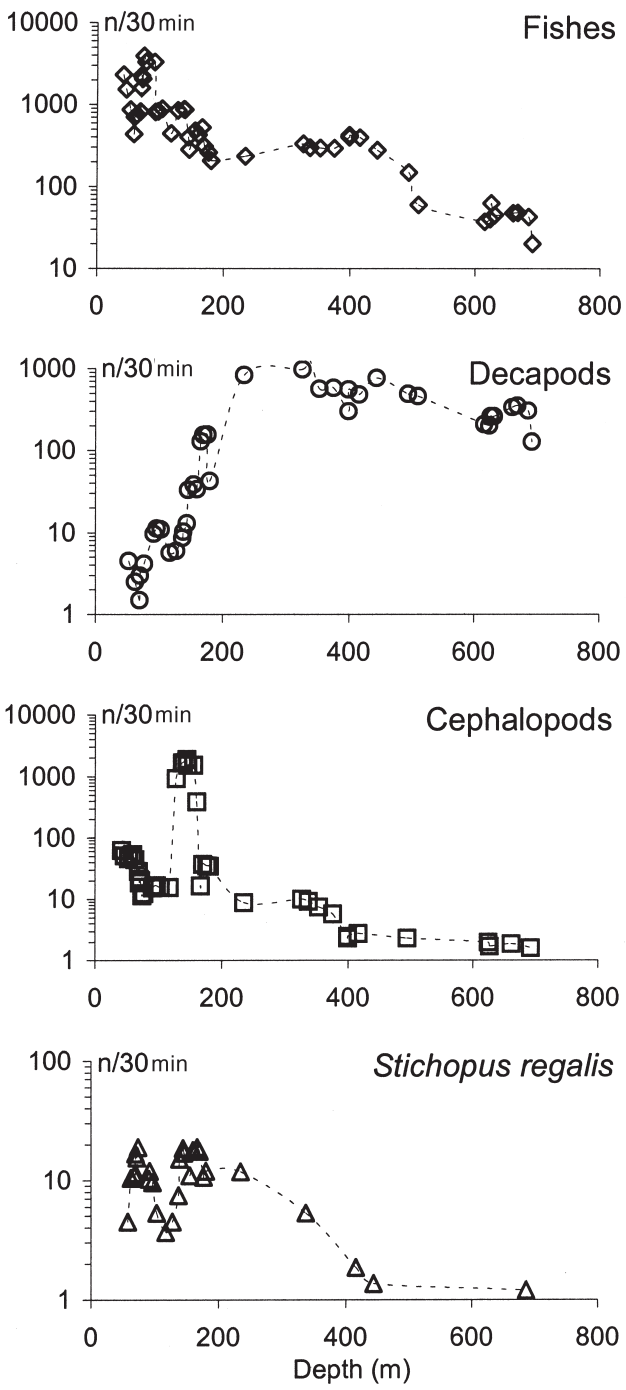

FIG. 2. - Distribution by depth and survey (BALAR0401 and BALAR0901) of the abundance (individuals/30 min) of the main groups considered (fishes, decapod crustaceans and cephalopod molluscs) and the only commercial holothuroid echinoderm (Stichopus regalis). 


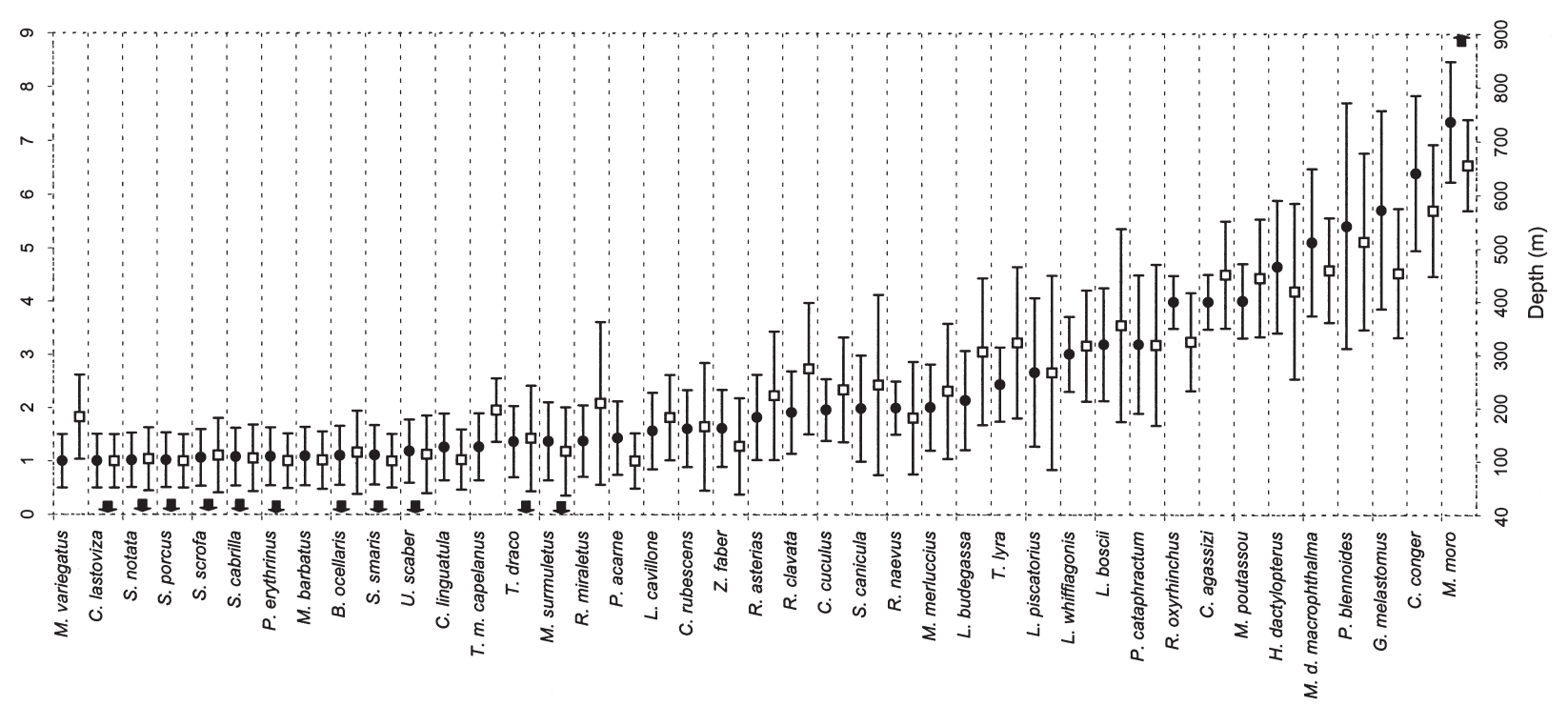

FIG. 3. - Bathymetric distribution of fish species in terms of centre of gravity and habitat from the BALAR0401 (black circles) and BALAR0901 (white squares) surveys. Black arrows indicate a displacement in real terms of the centre of gravity beyond the depth range sampled, according to other studies conducted in the same and adjacent areas (Reñones et al., 1995; Massutí et al., 1996; Moranta et al., 1998). Numbers 1-8 correspond to the eight depth intervals into which the sampled bathymetric range was divided (see Material and Methods). Full species names are given in Table 2.

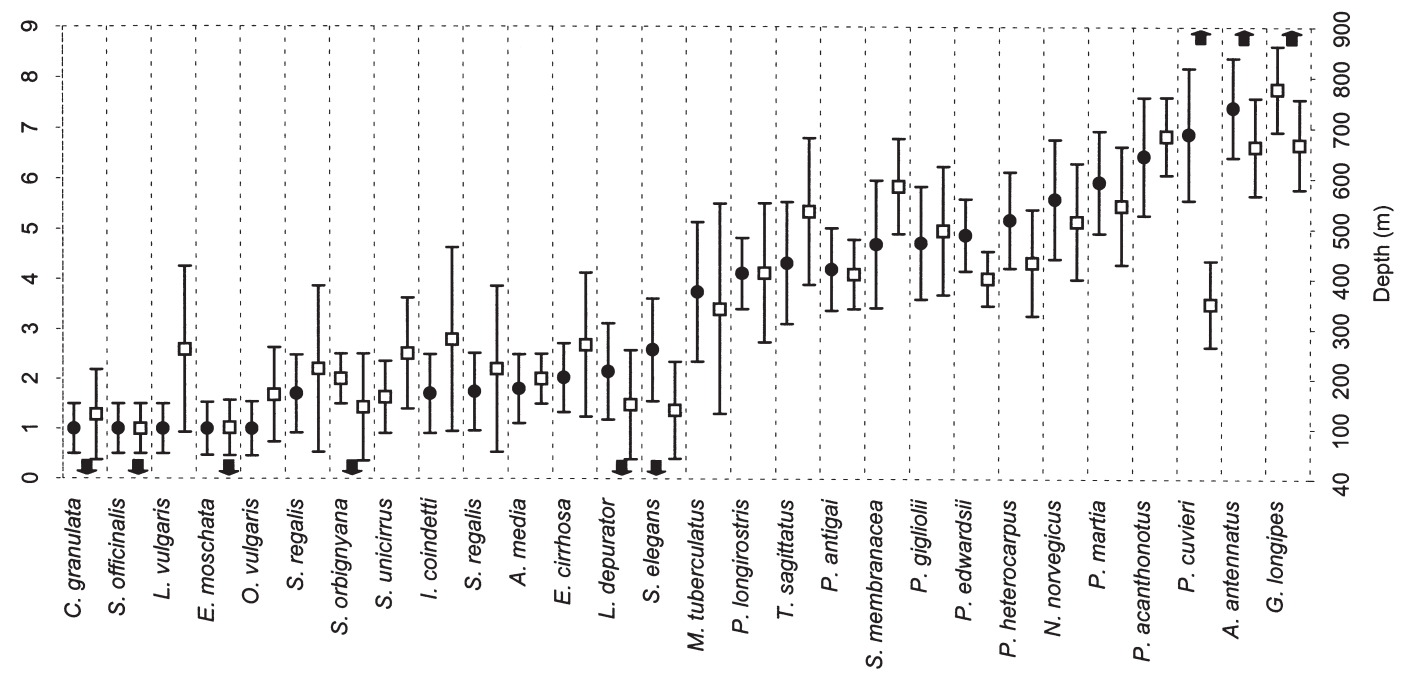

FIG. 4. - Bathymetric distribution of invertebrate species (decapod crustaceans, cephalopod molluscs and the holothurian echinoderm) in terms of centre of gravity and habitat from the BALAR0401 (black circles) and BALAR0901 (white squares) surveys. Black arrows indicate a displacement in real terms of the centre of gravity beyond the depth range sampled, according to other studies conducted in the same and adjacent areas (Maynou and Cartes, 2000; Quetglas et al., 2000). Numbers 1-8 correspond to the eight depth intervals into which the bathymetric range sampled was divided (see Material and Methods). Full species names are given in Table 1.

depth was between 100 and $200 \mathrm{~m}$ during the two surveys.

The bathymetric distribution of the species is shown in Figures 3 and 4. Within the fishes, some species (e.g. Chelidonichthys lastoviza, Scorpaena spp., Serranus cabrilla, Pagellus spp., Mullus spp., Spicara smaris, Uranoscopus scaber and Trachinus draco) were restricted to depths shallower than 200 $\mathrm{m}$, whereas others (e.g. Chlorophthalmus agassizi, Micromesistius poutassou, Helicolenus dactylopterus, Phycis blennoides and Galeus melasto$m u s$ ) were found only below this depth. Within the invertebrate species, clear differences were observed between crustaceans and molluscs. While decapods, except for Calappa granulata, Liocarcinus depurator and Macropipus tuberculatus, were distributed below a depth of $300 \mathrm{~m}$, all cephalopods, with the only exception of Todarodes sagittatus, were restricted to a depth above $400 \mathrm{~m}$. From the 103 species analysed, 29 fishes and 18 invertebrates were restricted to the bathymetric range surveyed. Differences in the centre of gravity and habitat of some species width were observed by comparing the two surveys. 

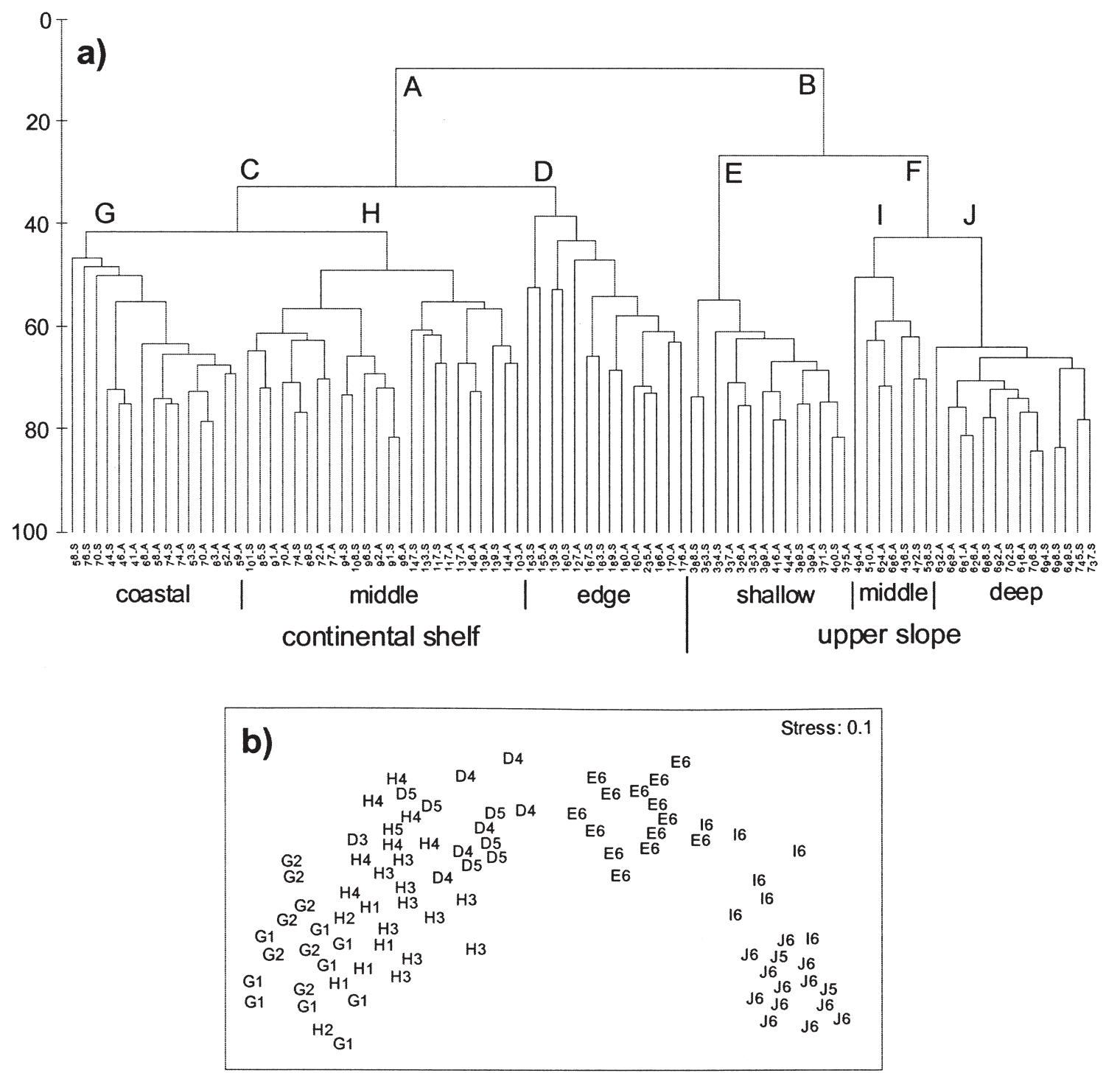

FIG. 5. - Dendrogram (a) and MDS diagram (b) of trawl samples obtained during the BALAR0401 and BALAR0901 surveys. In the dendrogram, mean depth (in metres) and season (S: spring; A: autumn) are shown for each station. In the MDS, the group obtained in the cluster analysis (letters) and the benthic community found (numbers; see Table 1 for details) are shown for each station. The stress of MDS ordination is indicated.

\section{Demersal resource associations}

Cluster analysis revealed the existence of six main groups of samples (Fig. 5a). The level of similarity of about $15 \%$ separated samples at depths between 41 and $235 \mathrm{~m}$ from those at depths between 326 and $745 \mathrm{~m}$ (noted as A and B in the figure). The level of similarity of about $30-35 \%$ separated samples at depths between 41 and $147 \mathrm{~m}$ from those at depths between 127 and $235 \mathrm{~m}(\mathrm{C}$ and $\mathrm{D}$ in the figure) and samples at depths between 326 and $444 \mathrm{~m}$ from those at depths between 436 and $745 \mathrm{~m}$ ( $\mathrm{E}$ and $\mathrm{F}$ in the figure). Finally, a third dichotomy was considered, which separated samples at depths between 41 and $76 \mathrm{~m}$ from those at depths between 69 and
$147 \mathrm{~m}$ ( $\mathrm{G}$ and $\mathrm{H}$ in the figure) and samples at depths between 436 and $686 \mathrm{~m}$ from those at depths between 616 and $745 \mathrm{~m}$ (I and J in the figure). The MDS analysis (Fig. 5b) confirmed the presence of six groups of samples $(\mathrm{G}, \mathrm{H}, \mathrm{D}, \mathrm{E}, \mathrm{I}$ and $\mathrm{J})$, which could be related to depth: on average, $60,106,167$, 377,537 and 678 respectively. These groups of samples were distributed on different macro-epibenthic communities, from coastal sandy and gravel detritic bottoms (group $\mathrm{G}$ ) to bathyal muddy soft bottoms (groups E, I and J).

The average dissimilarity between the six groups (Table 3) ranged from $78 \%$ (between I and J) to 99\% (between $\mathrm{G}$ and $\mathrm{I}$ and $\mathrm{J}$ and between $\mathrm{H}$ and $\mathrm{I}$ and $\mathrm{J}$ ). These differences were due to the distinct contribu- 
TABLE 3. - SIMPER results: Average dissimilarity (\%) between the six groups of samples identified from the cluster and MDS analyses.

\begin{tabular}{lccccc}
\hline & G & H & D & E & I \\
\hline H & 86.33 & & & & \\
D & 92.38 & 84.67 & & & \\
E & 98.48 & 97.39 & 92.05 & & \\
I & 99.89 & 99.67 & 97.95 & 86.51 & \\
J & 99.94 & 99.80 & 98.48 & 94.01 & 77.73 \\
\hline
\end{tabular}

tion of species in each group (Table 4), with 10, 13, $11,9,3$ and 3 species representing more than $90 \%$ of the groups G, H, D, E, I and J respectively. The following species could be considered as the main species of each group: (i) S. cabrilla, C. lastoviza, Octopus vulgaris and Mullus surmuletus for group G; (ii) Lepidotrigla cavillone, S. smaris and Scyliorhinus canicula for group $\mathrm{H}$; (iii) Chelidonichthys cuculus, Scyliorhinus canicula, Merluccius merluccius and Stichopus regalis for group D; (iv) Plesionika heterocarpus, Parapenaeus longirostris, C. agassizi and G. melastomus for group E; (v) Plesionika martia and P. blennoides for group I; and (vi) Aristeus antennatus and P. martia for group J.
The values of mean abundance and mean species richness for the different groups are shown in Table 5. The lowest values for all the parameters considered corresponded to group J. By contrast, the highest values of these parameters were obtained in group $\mathrm{H}$ for mean abundance and in group $\mathrm{E}$ for mean species richness.

\section{Differences between geographic sectors and seasons}

Due to the strong relationship between the groups of samples obtained and depth, the geographical and seasonal effects within each of the assemblages defined were examined, removing the effect of depth. MDS analysis showed geographical and/or seasonal aggregations between samples in three of the six assemblages defined (Fig. 6): G, D and $\mathrm{E}$.

Geographic differences were detected (ANOSIM: $\mathrm{R}=0.51, \mathrm{p}=0.8$ ) within group $\mathrm{G}$ (Fig. 6a). These differences were mainly due to the higher abundance of Mullus barbatus, C. lastoviza and $M$. surmuletus in the western sector, whereas $S$. smaris and $S$. cabrilla were more abundant in the

TABLE 4. - SIMPER results: mean abundance (A as individuals/30 min; \pm standard error) and percentage contribution to the similarity of each group $(\%)$ of species that contributed to at least $90 \%$ of the differences between the six groups of samples identified from cluster and MDS analyses.

\begin{tabular}{|c|c|c|c|c|c|}
\hline & A & $\%$ & & A & $\%$ \\
\hline Group G & & & Group D & & \\
\hline Serranus cabrilla & $94.1 \pm 25.1$ & 24.6 & Chelidonichthys cuculus & $99.8 \pm 53.7$ & 23.6 \\
\hline Chelidonichthys lastoviza & $95.1 \pm 21.2$ & 21.6 & Scyliorhinus canicula & $49.4 \pm 14.3$ & 20.8 \\
\hline Octopus vulgaris & $28.0 \pm 4.8$ & 9.9 & Merluccius merluccius & $60.7 \pm 19.8$ & 19.4 \\
\hline Mullus surmuletus & $84.2 \pm 30.6$ & 9.3 & Stichopus regalis & $14.5 \pm 3.6$ & 9.3 \\
\hline Scorpaena notata & $21.9 \pm 4.6$ & 7.1 & Mullus surmuletus & $9.3 \pm 3.7$ & 4.9 \\
\hline Scyliorhinus canicula & $46.1 \pm 15.9$ & 6.8 & Lepidorhombus boscii & $6.1 \pm 1.7$ & 3.4 \\
\hline Trachinus draco & $12.8 \pm 2.3$ & 3.8 & Alloteuthis media & $92.1 \pm 80.1$ & 2.8 \\
\hline Mullus barbatus & $143.5 \pm 83.5$ & 3.2 & Phycis blennoides & $3.8 \pm 1.0$ & 1.9 \\
\hline Scorpaena scrofa & $7.9 \pm 1.3$ & 3.0 & Lophius budegassa & $3.2 \pm 0.9$ & 1.9 \\
\hline \multirow[t]{2}{*}{ Spicara smaris } & $233.4 \pm 189.0$ & 2.2 & Macropipus tuberculatus & $9.1 \pm 5.2$ & 1.5 \\
\hline & & & Illex coindetti & $4.1 \pm 1.2$ & 1.2 \\
\hline Group $\mathrm{H}$ & & & Group E & & \\
\hline Lepidotrigla cavillone & $111.2 \pm 40.7$ & 23.2 & Plesionika heterocarpus & $226.9 \pm 94.6$ & 17.4 \\
\hline Spicara smaris & $623.3 \pm 367.3$ & 16.0 & Parapenaeus longirostris & $75.7 \pm 20.1$ & 14.7 \\
\hline Scyliorhinus canicula & $44.1 \pm 9.9$ & 10.1 & Chlorophthalmus agassizi & $80.0 \pm 4.5$ & 13.7 \\
\hline Alloteuthis media & $361.2 \pm 196.6$ & 6.2 & Galeus melastomus & $76.1 \pm 21.5$ & 12.0 \\
\hline Merluccius merluccius & $34.4 \pm 10.1$ & 6.0 & Micromesistius poutassou & $43.2 \pm 17.0$ & 7.6 \\
\hline Trachinus draco & $22.0 \pm 5.0$ & 5.8 & Plesionika gigliolii & $43.6 \pm 12.4$ & 7.5 \\
\hline Stichopus regalis & $22.2 \pm 6.6$ & 5.3 & Plesionika antigai & $52.6 \pm 17.0$ & 7.4 \\
\hline Chelidonichthys cuculus & $49.3 \pm 16.3$ & 4.7 & Helicolenus dactylopterus & $34.6 \pm 8.7$ & 6.7 \\
\hline Mullus surmuletus & $42.6 \pm 13.8$ & 4.4 & Phycis blennoides & $26.9 \pm 6.3$ & 5.4 \\
\hline Mullus barbatus & $43.5 \pm 23.8$ & 3.5 & Group I & & \\
\hline Serranus cabrilla & $18.5 \pm 4.7$ & 3.1 & Plesionika martia & $324.6 \pm 3.0$ & 72.5 \\
\hline Citharus linguatula & $13.8 \pm 6.2$ & 1.3 & Phycis blennoides & $39.9 \pm 12.4$ & 11.6 \\
\hline \multirow[t]{4}{*}{ Scorpaena notata } & $32.4 \pm 16.9$ & 1.3 & $\begin{array}{l}\text { Plesionika gigliolii } \\
\text { Group J }\end{array}$ & $31.2 \pm 14.3$ & 7.1 \\
\hline & & & Aristeus antennatus & $136.0 \pm 25.3$ & 71.8 \\
\hline & & & Plesionika martia & $27.5 \pm 7.6$ & 13.9 \\
\hline & & & Phycis blennoides & $9.4 \pm 1.5$ & 5.9 \\
\hline
\end{tabular}


TABLE 5. - Mean values ( \pm standard error) of species richness and abundance for each group identified in the cluster and MDS analyses. Mean depth ( \pm standard deviation), depth range and the numbers of samples of each group are also shown.

\begin{tabular}{|c|c|c|c|c|c|c|}
\hline & $\mathrm{G}$ & $\mathrm{H}$ & $\mathrm{D}$ & $\mathrm{E}$ & I & $\mathrm{J}$ \\
\hline Mean species richness & $16.9( \pm 0.8)$ & $15.9( \pm 0.6)$ & $18.3( \pm 0.7)$ & $20.4( \pm 0.5)$ & $16.0( \pm 2.2)$ & $9.8( \pm 0.6)$ \\
\hline Mean depth (m) & $60( \pm 11.4)$ & $106( \pm 26.4)$ & $167( \pm 25.0)$ & $377( \pm 33.9)$ & $537( \pm 88.4)$ & $678( \pm 39.4)$ \\
\hline Depth range $(\mathrm{m})$ & $41-76$ & 69-147 & $139-235$ & $326-444$ & $472-686$ & $649-745$ \\
\hline Number of samples & 15 & 24 & 14 & 14 & 7 & 14 \\
\hline
\end{tabular}

\begin{tabular}{|c|c|c|c|}
\hline Group G & \multicolumn{2}{|c|}{ SW1 } & Stress: 0.13 \\
\hline sW1 & \multicolumn{2}{|r|}{ AE2 } & SE2 \\
\hline \multirow{4}{*}{$\begin{array}{l}\text { AW1 } \\
\text { AW1 }\end{array}$} & AW1 & & \\
\hline & \multicolumn{2}{|c|}{ AE1 } & \\
\hline & AE1 & SE1 & SE2 \\
\hline & $\mathrm{AE} 2$ & AE2 & \\
\hline & & & \\
\hline
\end{tabular}
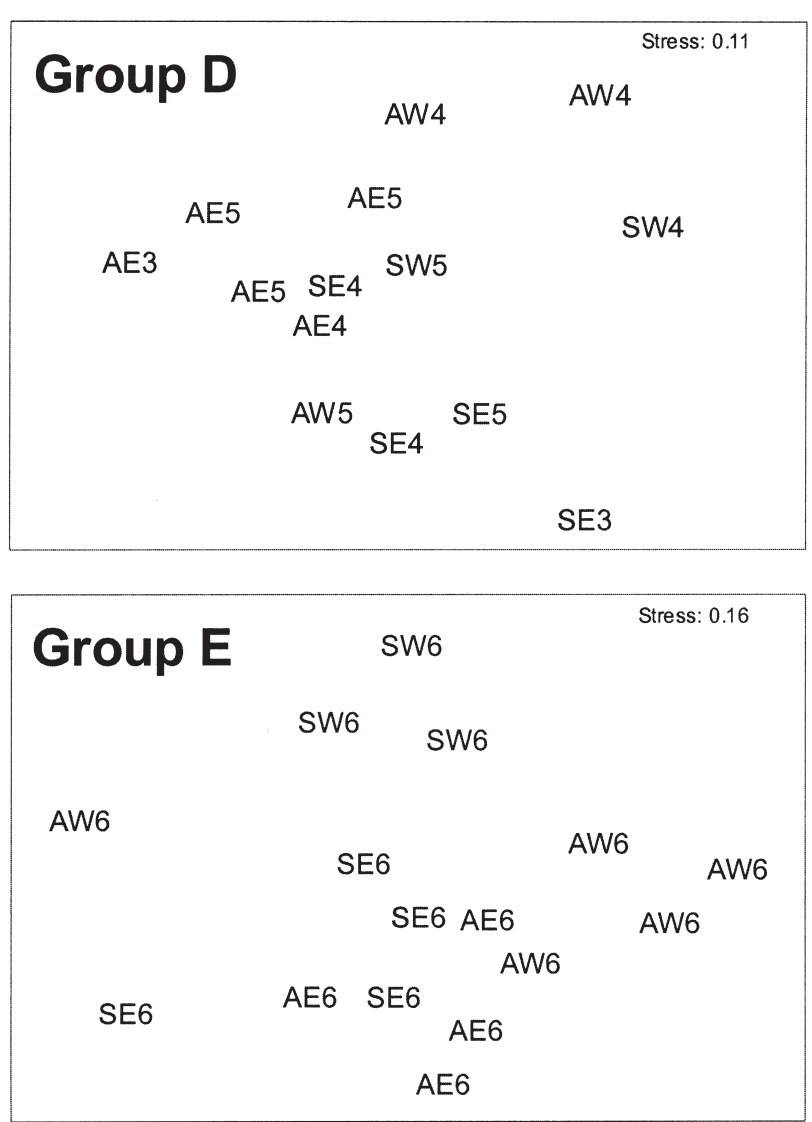

FIG. 6. - MDS diagram applied to the groups of samples C, D and E, identified from the cluster and MDS analyses (see Figure 5), which showed seasonal (S: spring; A: autumn) and/or geographical (W: west; E: east) differences. The benthic community found (numbers; see Table 1 for details) are shown for each station. The stress of MDS ordination is indicated. eastern sector. Although group $\mathrm{G}$ was found on sandy and gravel detritic bottoms, all samples from the western sector were associated with soft red and green algae, while samples from the eastern sector were distributed mainly on calcareous red algae.

Group D (Fig. 6b) showed geographical (ANOSIM: $\mathrm{R}=0.42, \mathrm{p}=1.2$ ) and seasonal (ANOSIM: $\mathrm{R}=0.40, \mathrm{p}=0.8$ ) differences, with five species accounting for nearly $65 \%$ of this dissimilarity. In autumn, higher abundances were shown by C. cuculus and S. canicula in the eastern sector and by the cephalopod Alloteuthis media in the western sector. On the other hand, M. merluccius was more abundant in the eastern sector and showed a weak increase in spring.

Geographical (ANOSIM: $\mathrm{R}=0.30, \mathrm{p}=2.4$ ) and seasonal (ANOSIM: $\mathrm{R}=0.27, \mathrm{p}=3.9$ ) differences were also detected in group E (Fig. 6c). These seasonal differences were due mainly to the greater abundance of the decapods $P$. heterocarpus, Plesionika edwardsii and P. martia during autumn, together with the fishes G. melastomus and C. agassizii. In addition, all of them, except for this latter species, were more abundant in the western sector.

\section{Accompanying macro-epibenthos}

Clear differences were observed by comparing mean standardised total catch and the proportion and composition of non commercial macro-epibenthic species between the different groups identified from the cluster and MDS analyses (Fig. 7).

Group $\mathrm{G}$ showed the highest catch rates and percentages of non-commercial species, in which algae and echinoderms clearly predominated, while the lowest values of these parameters were obtained in groups I and $\mathrm{J}$, in which fish, echinoderms and molluscs predominated within non-commercial species. The percentage of non-commercial species was also important and similar in groups $\mathrm{H}$ and $\mathrm{D}$, with echinoderms as the main important group, but differences were observed in the catch rate, whose value in group $\mathrm{H}$ was higher than in group $\mathrm{D}$. 

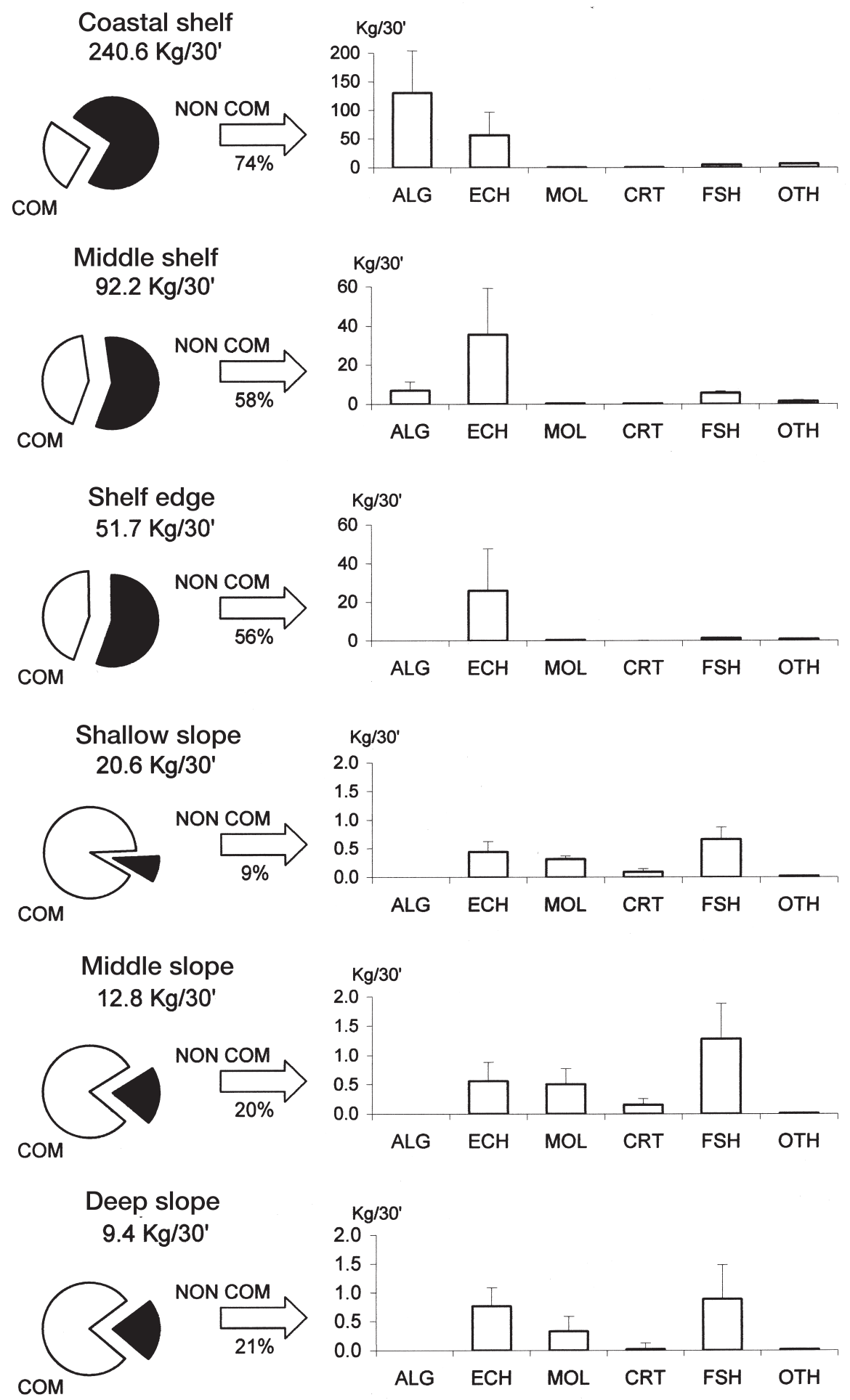

FIG. 7. - Mean standardised total catch ( $\mathrm{kg} / 30 \mathrm{~min})$, proportion and composition of non-commercial macro-epibenthic species for each group identified in the cluster and MDS analyses. The main taxonomic groups algae (ALG), echinoderms (ECH), molluscs (MOL), crustaceans (CRT), fishes (FSH) were considered. The less abundant taxons were grouped as "others" (OTH; see Material and Methods for details).

\section{DISCUSSION}

The quantitative analysis of the demersal resources distributed in the trawl fishing grounds on the continental shelf and upper slope off Mallorca and Menorca Islands revealed the existence of six main species assemblages, which could be related to the following approximate depth intervals: (i) 40-80 m; (ii) $80-150 \mathrm{~m}$; (iii) $150-250 \mathrm{~m}$; (iv) $250-450 \mathrm{~m}$; (v) $450-600 \mathrm{~m}$; and (vi) $600-800 \mathrm{~m}$. Thus, the bathy- 
metric gradient was the principal factor for these species associations. Depth is generally considered as the most important environmental gradient in the sea and has been shown to be the main factor determining the distribution of marine fauna (e.g. Gage and Tyler, 1991). Seasonal differences in the bathymetric distribution of the species, shown by a displacement of their centre of gravity and a change in habitat width, have also been found. The possible explanatory causes of these temporal changes are far from being well known, but some causes, probably inter-correlated, can be argued. According to Kallianiotis et al. (2000), "water temperature over the continental shelf starts to increase in early spring and fish that winter there, gradually migrate to their spawning grounds. After spawning most fish begin their feeding migration in summer and during autumn the massive recruitment migration occurs. The fish populations return to wintering areas as the temperature decrease". Upward-downward movements of some species along the slope to feed in more productive zones and migrations linked to their life cycle (e.g. spawning and recruitment) have also been suggested for fish and decapods (e.g. Sardà et al., 1994a, 1994b).

The influence of depth is revealed not only at a species level but also by considering major taxonomic groups. Fish and cephalopods show a decrease in density with increasing depth, from their maximum on the continental shelf, where they are the dominant demersal resources, whereas decapods dominate on the upper slope, where they reach their maximum abundance. Similar trends have been obtained in the central (Colloca et al., 2003) and eastern Mediterranean (Labropoulou and Papaconstantinou, 2000). In the same study area, the bathymetric segregation of different assemblages has already been demonstrated for different taxonomic groups (Massutí et al., 1996; Quetglas et al., 2000). However, the comparison of our results with these studies, which only made a qualitative analysis of fish and cephalopod species respectively, revealed that the distribution of the demersal resources is more complex than that previously found (only four assemblages). Moreover, the comparison of our results with those obtained from the quantitative analysis of different taxonomic groups undertaken in other areas of the Mediterranean also shows that the bathymetric distribution of demersal resources, considered as a whole, is also more complex than those associations found within the separated groups of cephalopods, crustaceans and fishes (González and Sánchez, 2002; Maynou and Cartes, 2000; Demestre et al., 2000; respectively). On the other hand, our results are similar to those obtained from the analysis of the whole demersal macrofauna developed in the central (Biagi et al., 2002; Colloca et al., 2003) and eastern (Kallianiotis et al., 2000) Mediterranean, which identified assemblages on the coastal shelf, middle shelf, shelf-edge, shallow upper-slope and deep upper-slope.

The different types of macro-epibenthic communities are also an important factor for the association of demersal resources. The coastal assemblage is found on detritic sandy and gravel bottoms, characterised by a large amount of algae and echinoderm biomass (larger than those of the exploited species). In fact, it has been estimated that non-commercial species represent up to $75 \%$ of the biomass captured, but discarded, in the trawl fishery carried out in these fishing grounds (Carbonell et al., 1998). These coralligenous and maërl communities are very characteristic of the Mallorca-Menorca shelf up to 85-90 m depth (Canals and Ballesteros, 1997) and could be the reason for some differences observed in the coastal demersal resource structure of the Balearic Islands and the Iberian coast. M. surmuletus is more abundant than M. barbatus in insular shelf assemblages and the opposite situation is found closer to the mainland (Lombarte et al., 2000; Tserpes et al., 2002). M. surmuletus prefers the narrow continental shelf off the Balearic Islands, where rocky, carbonate and gravel bottoms predominate, while $M$. barbatus prefers areas where the shelf becomes wider and muddy bottoms of a terrigenous origin, which are more common off the Iberian coast.

Two facies differentiated by Pérès (1985) in the coastal detritic community have been found, with some differences in their distribution. One is dominated by calcareous red algae (maërl) and is mainly found on the east coast of Mallorca and the channel between Mallorca and Menorca. The other one is dominated by soft red and green algae, located mainly on the west and south coast of Mallorca. These differences in habitats, that could be on the basis of the geographical variations found in the coastal assemblage, can be related to different hydrodynamic conditions. The channel between Mallorca and Menorca is more affected by strong northerly winds and offshore currents (Pinot et al., 1995), therefore being a favourable area for the development of the maërl facies (Pérès, 1985). On the other hand, the bay of Palma is more affected by 
southerly winds, being a region of weakened currents more favourable for the accumulation of particles (Werner et al., 1993) and hence for amassing the less dense soft red algae, a facies that only develops at the mouth of open bays (Pérès, 1985).

Middle shelf and shelf edge assemblages are mainly distributed on muddy-detritic and shelf-edge detritic communities, in which echinoderms (mainly large sea urchins) are very abundant. Non-commercial and commercial species are captured in a similar proportion in these fishing grounds, where the sediment consists of a mixture of gravel together with some sand, mud and many remnants from benthic organisms (Pérès, 1985). Similar bottoms, but characterised by the presence of Gryphus vitreus, have been found on the outer continental shelf and upper slope. These bottoms with large brachiopods have been described in straits between large islands or between an island and the continent (Pérès, 1985). The three characterised upper slope assemblages are distributed on bathyal muddy soft fishing grounds, which show a clear reduction in biomass and in the proportion of non-commercial species. In the western Mediterranean, an association of decapods on Funiculina quadrangularis and Isidella elongata prairies has been observed at these depths, although the effect of trawling on these bottoms, removing these large erect cnidarians, has changed their bionomy (Gili et al., 1987).

The geographic and seasonal differences found in the shelf edge and the shallower upper slope assemblages could be related to different abiotic and biotic factors. The higher abundance of Plesionika species in the western sector could be due to the absence of submarine canyons in this area (the only submarine canyon is located on the southern coast of Menorca; Canals and Ballesteros, 1997), which can contribute to a distinct trophic web structure and energy flow in deep-sea ecosystems. According to Maynou and Cartes (2000), deposit and infaunal feeder species are more characteristic of communities in which the inputs of organic carbon via submarine canyons are an additional source of food resources, while the pandalids dominate on demersal communities whose trophic resources are of planktonic origin. In addition, the seasonal differences in species of the genus Plesionika can be related to their reproductive pattern. The major abundance of $P$. edwardsi and $P$. martia during autumn could be due to the fact that their maximum reproduction occurs during spring and summer (Company and Sardà, 1997), which therefore leads to the subsequent recruitment of these species in autumn. Recruitment could also be on the basis of the predominance in spring of M. merluccius, a species that in the northwestern Mediterranean shows a maximum recruitment during this season (Maynou et al., 2003). Similarly, the recruitment in the study area of S. canicula, which shows higher abundance in autumn, has been reported during summer-winter (Carbonell et al., 2003). These authors also estimated a higher abundance for the species in the eastern sector, suggesting that it could be caused by a lesser fishing effort in this area.

In conclusion, the existence of well-defined demersal resource assemblages, distributed on different macro-epibenthic communities, should be taken into account for future assessment and management of trawl fishery in the Balearic Islands. It could contribute to the development of multispecies and massbalance models for the assessment of this fishery, a methodology that has increasingly been considered for the study of fisheries (e.g. Sánchez and Olaso, 2004). It could also complement the identification of fishing strategies within the fishery (Alemany and Álvarez, 2003). The management of trawl fishery should be based more on the ecosystem, with the objective of maintaining both resources and communities. This is especially necessary for coastal detritic bottoms and their maërl community, which are widespread and characteristic of the coastal fishing grounds off the Balearic Islands. This community hosts nursery areas for many species of commercial interest (Keegan, 1974), it is characterised by a high biological diversity and is high sensitive to anthropic impacts (Hall-Spencer and Moore, 2000). In fact, the importance of maërl beds has led to their inclusion in the European Union Habitats Directive 92/42/EEC and the Red Book of Threatened Seascapes (UNEP/UICN/GIS Posidonie, 1990). Lastly, from the above, it is considered necessary to undertake future research to study the quantitative aspects and biological production of these bottoms off the Balearic Islands.

\section{ACKNOWLEDGEMENTS}

This paper is a result of the MEDER project, financed by IEO. The authors wish to thank the crew of the R/V Francisco de Paula Navarro, Aina Carbonell, Ángel Carpena, Ángel Fernández, José L. Fernández, Iñaki Franco, María González, Beatriz Guijarro, José A. Martínez, Guillem Mateu, Biel 
Pomar, Arantza Ramos and Anna Torres for their help during the sampling, as well Dr. C. Rodgers and M.C. Iglesias for their help in improving the manuscript. We also thank Pep Blanca, Jaume Enseñat, Carlos García, Rafel Mas, Joan Llitrà, Quique Martín, Miquel Sans, Pep Uceda and Joan J. Vaquero, skippers of the fishing vessels "Josep de Paraguay", "Villa de Sóller", "Bellver", "Illa del Sol", "Toni Mollet", "Carretero", "Rosa Santa", "Joven Mirmer" and "Moralti Nou", for their help during the preparation of the surveys.

\section{REFERENCES}

Abelló, P., A. Carbonell and P. Torres. - 2002. Biogeography of epibenthic crustaceans on the shelf and upper slope off the Iberian Peninsula Mediterranean coasts: implications for the establishment of natural management areas. Sci. Mar., 66(Suppl. 2): 183-198.

Alemany, F. and F. Álvarez. - 2003. Determination of effective fishing effort on hake Merluccius merluccius in a Mediterranean trawl fishery. Sci. Mar., 67: 491-499.

Bertrand, J.A., L. Gil de Sola, C. Papaconstantinou, G. Relini and A. Souplet. - 2002. The general specifications of the MEDITS surveys. Sci. Mar., 66(Suppl. 2): 9-17.

Biagi, F., P. Sartor, G.D. Ardizzone, P. Belcari, A. Belluscio and F. Serena. - 2002. Analysis of demersal assemblages off the Tuscany and Latium coasts (north-western Mediterranean). Sci. Mar., 66(Suppl. 2): 233-242.

Caddy, J.F. - 1993. Some future perspectives for assessment and management of Mediterranean fisheries. Sci. Mar., 57: 121-130.

Caddy, J.F. and G.D. Sharp. - 1986. An ecological framework for marine fisheries investigation. FAO Fish. Tech. Pap., 283: 1-152.

Canals, M. and E. Ballesteros. - 1997. Production of carbonate particles by phytobenthic communities on the MallorcaMenorca shelf, northwestern Mediterranean Sea. Deep-Sea Res., 44, 611-629

Carbonell, A. - 1997. Discards of the western Mediterranean trawl fleets. Final Report Contract DGXIV-MED/94/027, 142 pp.

Carbonell, A., P. Martín, S. De Ranieri and WEDIS team. - 1998. Discards of the western Mediterranean trawl fleets. Rapp. Comm. Int. Mer Médit., 35: 392-393.

Carbonell, A., F. Alemany, P. Merella, A. Quetglas and E. Román. -2003 . The by-catch of sharks in the western Mediterranean (Balearic Islands) trawl fishery. Fish. Res., 61: 7-18.

Carbonell, A. and M. Azevedo. - 2003. Application of non-equilibrium production models to the red shrimp (Aristeus antennatus, Risso, 1816) fishery in the northwestern Mediterranean. Fish. Res., 65: 323-334.

Clarke, K.R. and R.M. Warwick. - 1994. Changes in Marine comunities: an approach to statistical analysis and interpretation. Natural Environment Research Council; Plymouth.

Clifford, H. and W. Stephenson. - 1975. An introduction to numerical classification. Academic Press, New York.

Colloca, F., M. Cardinale, A. Belluscio and G. Ardizzone. - 2003. Pattern of distribution and diversity of demersal assemblages in the central Mediterranean sea. Est. Coast. Shelf Sci., 56: 469480 .

Company, J.B. and F. Sardà. - 1997. Reproductive patterns and population characteristics in five deep-water pandalid shrimps in the Western Mediterranean along a depth gradient (150-1100 m). Mar. Ecol. Prog. Ser., 148: 49-58.

Daget, P. - 1976. Ordinations des profiles ecologiques. Natural. Monspel., Sér. Bot., 26: 109-128.

Demestre, M., P. Sánchez and P. Abelló. - 2000. Demersal fish assemblages and habitat characteristics on the continental shelf and upper slope of the north-western Mediterrranean. J. Mar. Biol. Ass. U.K., 80: 981-988.

Ellis, J.R., S.I. Rogers and S.M. Freeman. - 2000. Demersal assem- blages in the Irish Sea, St. George's Channel and Bristol channel. Est. Coast. Shelf Sci., 51: 299-315.

Fernández de Puelles, M.L., J. Valencia and L. Vicente. - Zooplankton variability and climatic anomalies from 1994 to 2001 in the Balearic Sea (Western Mediterranean). ICES J. Mar. Sci., 61: 492-500

Gage, J.D. and P.A. Tyler. - 1991. Deep-Sea Biology: a natural history of organisms at the deep-sea floor. Cambridge University Press.

García-Rodríguez, M. and A. Esteban. - 1999. On the biology and fishery of Aristeus antennatus (Risso, 1816) (Decapoda, Dendrobranchiata) in the Ibiza channel (Balearic Islands, Spain). Sci. Mar., 63: 27-37.

Gili, J.M., J.D. Ros and F. Pagès. - 1987. Types of bottoms and benthic Cnidaria from the trawling grounds (littoral and bathyal) off Catalonia (NE Spain). Vie Milieu, 37: 85-98.

González, M. and P. Sánchez. - 2002. Cephalopod assemblages caught by trawling along the Iberian Peninsula Mediterranean coast. Sci. Mar., 66 (Suppl. 2): 199-208.

Hall-Spencer, J.M. and P.G. Moore. - 2000. Impact of scallop dredging on maërl grounds. In: M.J. Kaiser and S.J. de Groot (eds.), Effects of Fishing on Non-Target Species and Habitats, pp. 105-117. Blackwell Science Ltd, Oxford.

Kallianiotis, A., K. Sophronidis, P. Vidoris and A. Tselepides. 2000. Demersal fish and megafaunal assemblages on the Cretan continental shelf and slope (NE Mediterranean): seasonal variation in species density, biomass and diversity. Prog. Oceanogr., 46: 429-455.

Keegan, B. - 1974 The macrofauna of maërl substrates on the west coast of Ireland. Cah. Biol. Mar., 15: 513-530.

Labropoulou, M. and C. Papaconstantinou. - Community structure of deep-sea demersal fish in the North Aegean Sea (northeastern Mediterranean). Hydrobiologia, 440: 281-296.

Lleonart, J. and F. Maynou. - 2003. Fish stock assessments in the Mediterranean: state of the art. Sci. Mar., 67(Suppl. 1): 37-49.

Lombarte, A., L. Recasens, M. González and L. Gil de Sola. -2000. Spatial segregation of two species of Mullidae (Mullus surmuletus and M. barbatus) in relation to habitat. Mar. Ecol. Prog. Ser., 206: 239-249.

Massutí, M. - 1991. Les Illes Balears, un área de pesca indvidualitzada a la Mediterrània Occidental. Quaderns de Pesca, 2: $1-62$.

Massutí, E., O. Reñones, A. Carbonell and P. Oliver. - 1996. Demersal fish communities exploited on the continental shelf and slope off Majorca (Balearic Islands, NW Mediterranean). Vie Milieu, 46(1), 45-55.

Maynou, F. and J.E. Cartes. - 2000. Community structure of bathyal decapod crustaceans off south-west Balearic Islands (western Mediterranean): seasonality and regional patterns in zonation. J. Mar. Biol. Ass. UK, 80: 789-798.

Moranta, J., C. Stefanescu, E. Massutí, B. Morales-Nin and D. Lloris. - 1998. Fish community structure and depth-related trends on the continental slope of the Balearic Islands (Algerian basin, western Mediterranean). Mar. Ecol. Prog. Ser., 171: 247-259.

Moranta, J., E. Massutí and B. Morales-Nin. - 2000. Fish catch composition of the deep-sea decapod crustacean fisheries in the Balearic Islands (w:estern Mediterranean). Fish. Res., 45: 253-264.

Oliver, P. - 1993. Analysis of fluctuations observed in the trawl fleet landings of the Balearic Islands. Sci. Mar., 57(2-3): 219227.

Pérès, J.M. - 1985. History of the Mediterranean Biota and the Colonization of the Depths. In: R. Margalef (ed.), Western Mediterranean, pp. 198-232. Pergamon Press, London.

Pielou, E.C. - 1969. An introduction to mathematical ecology. Wiley, New York.

Pinot, J.-M., J. Tintoré and D. Gomis. - 1995. Multivariate analysis of the surface circulation in the Balearic Sea. Prog. Oceanogr., 36: $343-376$.

Pinot, J.-M., J.L. López-Jurado and M. Riera. - 2002. The CANALES experiment (1996-1998). Interannual, seasonal, and mesoscale variability of the circulation in the Balearic Channels. Prog. Oceanogr., 55: 335-370.

Quetglas, A., A. Carbonell and P. Sánchez. - 2000. Demersal Continental Shelf and Upper Slope Cephalopod Assemblages from the Balearic Sea (North-Western Mediterranean). Biological Aspects of Some Deep-Sea Species. Est. Coast. Shelf Sci., 50: 
739-749.

Reñones, O., E. Massutí, J. Moranta, J. Coll and I. Moreno. - 1995.

Fish fauna of Posidonia oceanica seagrass meadows in Palma Bay (Balearic Islands). Cybium, 19: 201-206.

Sánchez F and I. Olaso - 2004. Effects of fisheries on the Cantabrian Sea shelf ecosystem. Ecol. Model., 172: 151-174.

Sardà, F., J.E. Cartes and J.B. Company. - 1994a. Spatio-temporal variations in megabenthos abundance in three different habitat of the Catalan deep-sea (Western Mediterranean). Mar. Biol. 120: 211-219.

Sardà, F., J.E. Cartes and W. Norbis. - 1994b. Spatio-tempora structure of the deep-water shrimp Aristeus antennatus (Decapoda: Aristeidae) population in the western Mediterranean. Fish. Bull., 92: 599-607.
Tserpes, G., F. Fiorentino, D. Levi, A. Cau, M. Murenu, A. Zamboni and C. Papaconstantinou. - 2002. Distribution of Mullus barbatus and M. surmuletus (Osteichthyes: Perciformes) in the Mediterranean continental shelf: implications for management. Sci. Mar., 66(Suppl. 2): 39-54

UNEP/UICN/GIS Posidonie. - 1990. Libre rouge "Géread Vuignier" des vegetaux, peuplements et payssages marins ménaces de Méditerranée. MAP Tech. Rep. Ser., 43: 1-250.

Werner, F.E., A. Viúdez and J. Tintoré. - 1993. An exploratory numerical study of the currents off the southern coast of Mallorca including the Cabrera island complex. J. Mar. Sys., 4: 4566.

Scient. ed.: P. Abelló 
